"This is the peer reviewed version of the following article: [Chen, Z., Gallagher, D. R. and Lee, A. D. (2016), Testing the effect of portfolio holdings disclosure in an environment absent of mandatory disclosure. Account Finance. doi:10.1111/acfi.12214], which has been published in final form at [http://dx.doi.org/10.1111/acfi.12214]. This article may be used for non-commercial purposes in accordance with Wiley Terms and Conditions for Self-Archiving." 


\title{
Testing the Effect of Portfolio Holdings Disclosure in an \\ Environment Absent of Mandatory Disclosure
}

\author{
Zhe Chen ${ }^{\mathrm{a}, \mathrm{b}}$, David R. Gallagher ${ }^{\mathrm{a}, \mathrm{b}, \mathrm{c}, \mathrm{d}}$, Adrian D. Lee ${ }^{\mathrm{e}}$ \\ ${ }^{a}$ Centre for International Finance and Regulation, Sydney, N.S.W. 2000 AUSTRALIA \\ ${ }^{b}$ UNSW Business School, UNSW Australia, Sydney N.S.W. 2052 AUSTRALIA \\ ${ }^{c}$ Capital Markets CRC Limited, Sydney N.S.W. 2000 AUSTRALIA \\ ${ }^{d}$ Macquarie Graduate School of Management, North Ryde, N.S.W. 2109 AUSTRALIA \\ ${ }^{e}$ University of Technology Sydney, Broadway, N.S.W. 2007 AUSTRALIA
}

\begin{abstract}
This study examines a number of portfolio disclosure regimes with respect to accuracy and susceptibility to copycat behavior in an environment absent of mandatory disclosure. We find that periodic portfolio disclosure tends to underestimate true excess performance as well as idiosyncratic risk in top-quartile fund managers, with longer interreporting intervals tending to result in greater differences. 'Copycat funds' following the disclosed holdings of top-tier managers significantly underperform the underlying fund, while copycats following bottom-tier managers significantly outperform the underlying fund. Our findings suggest that periodic reporting at monthly intervals or longer would not affect fund alpha generation.
\end{abstract}

JEL classification: G23

Keywords: Managed funds, portfolio holdings disclosure, copycat funds

* The authors gratefully acknowledge the assistance and support of the Centre for International Finance and Regulation (UNSW Australia).

†Corresponding author. E-mail address: zhe.chen@cifr.edu.au (Z. Chen). Postal address: Level 7, 1 O’Connell Street, Sydney, NSW 2000, Australia. Telephone: +61 299319319. 


\section{Introduction}

We investigate the trade-off between measurement accuracy and the leakage of commercially sensitive (valuable) information when portfolio holdings data is publically reported at varying frequencies and lags. Our study is unique in that we investigate the effect of portfolio holdings disclosure in the Australian regulatory environment, where formalised mandatory portfolio disclosure is absent, in contrast to the U.S. system. This means that funds are able to earn alpha without public scrutiny of their holdings, or the fear of being copied market-wide. Interestingly, Alpert, Rekenthaler and Suh (2013) document in the Morningstar Global Fund Investor Experience Report covering 24 countries, 'Australia and New Zealand still do not have regulations in place requiring portfolio information. ${ }^{11}$ In contrast, other studies on portfolio disclosure have focussed on the US market. The shift by the SEC in 2004 from semi-annual to quarterly reporting highlighted a number of issues concerning the relationship between disclosure frequency and fund performance/market quality. However no previous study ${ }^{2}$ has investigated the issues associated with switching from no holdings disclosure to some voluntary form of

\footnotetext{
1 The lack of portfolio holdings disclosure in Australia has seen the Australian government in recent times seek to introduce ${ }^{2}$ A notable exception is Brown, K. \& Gregory-Allen, R. B. 2012. The Potential Effects of Mandatory Portfolio Holdings Disclosure in Australia and New Zealand. Working Paper, Massey University. who investigate the effect on performance and fund inflows of Australian and New Zealand funds that voluntarily disclose fund holdings in the Morningstar database.
} 
disclosure, usually to asset consulting firms. Our study seeks to address this gap in the research. ${ }^{3}$

A number of arguments have been presented against both mandatory holdings disclosure and the implementation of more frequent disclosure regimes. The main concern is that third party investors are able to anticipate fund manager trades by looking at their recent holdings positions, and position themselves to front-run. Furthermore, freeloading fund managers may also be able to exploit the costly research that other funds have done through copycat strategies, and potentially undercut these funds on management fees. The combination of these behaviors has the potential to both increase transaction costs for entities that are required to periodically disclose their holdings, and reduce motivation for original research. Fund managers also typically cite concerns that revealing portfolio positions may enable others to reverse engineer their investment processes and strategies, thereby revealing the fund managers' intellectual property (IP).

Our access to high-granularity inter-day trading data enables us to go beyond the implied trades (derived from changes in holdings) that many prior studies have used, and

\footnotetext{
${ }^{3}$ It should be noted that Australia, since 1994, has operated a highly effective continuous disclosure regime for listed companies on the ASX that is policed (now) by the Australian Securities and Investments Commission (ASIC). An alternative disclosure regime for listed firms in the United States (Regulation Fair Disclosure) has operated since 2000 to remove selective private information from benefiting some in the market over others. See Beekes, W., Brown, P. \& Zhang, Q. 2014. Corporate governance and the informativeness of disclosures in Australia: a re-examination. Accounting \& Finance, Forthcoming, ibid.and Chapple, L. \& Truong, T. P. Ibid.Continuous disclosure compliance: does corporate governance matter? , 1-24. for details of continuous disclosure in Australia.
} 
enables us to contribute to this literature by investigating factor-adjusted returns and portfolio volatility on a daily level, which has not been previously possible. Our results show that hypothetical periodic portfolio disclosure tends to underestimate true excess fund performance. However, the measurement error is concentrated in top-quartile performing fund managers, with longer inter-reporting intervals tending to result in even greater differences. We also show that longer intervals between when holdings are disclosed potentially mean that investors may find it more difficult to identify genuinely skilled funds, while at the same time not fully realising the level of diversifiable risk they are taking on by investing in fund managers with top-tier performance.

The second part of this study ascertains the extent to which commercially sensitive information is leaked through periodic disclosure of holdings by simulating 'copycat funds' that emulate the reported holdings of a fund on a delayed basis (with delays ranging from one (1) month to one (1) year). We find that copycat funds, on average, do not perform significantly differently from their underlying funds (with the exception of annual reporting with a one month lag, in which case the copycat underperforms). However, partitioning the funds into performance quartiles show that copycat funds significantly underperform top-quartile funds at lags of six (6) months or shorter, while significantly outperforming bottom-quartile funds at lags of three (3) months or longer. 
The remainder of this paper is structured as follows: section 2 presents prior research on the effects and outcomes of mandatory portfolio disclosure; section 3 describes the data used in this study; section 4 details the research design and empirical results of determining disclosure accuracy and the effectiveness of potential copycat strategies; and section 5 concludes.

\section{Background}

Proponents in favor of portfolio holdings disclosure argue that greater availability of historical holdings data enables investors to make better-informed decisions about their choice of investment managers, which enhances competition, reduces fees, and increases the efficiency of the industry as a whole. Indeed, it has been shown that reporting frequency is positively related to the accuracy with which fund manager performance may be measured (e.g., see Bollen and Busse (2001)), and is an enabling factor for investors to predict future performance (e.g., see Elton, Gruber and Blake (2011)).

Even without full disclosure, earlier studies have shown that powerful inferences can be made regarding a fund manager's investment ability. For example, Wermers, Yao and Zhao (2012) use holdings-based analysis of fund portfolios to reveal differences in fund managers' abilities to predict firms' future earnings from fundamental factors that are not subsumed by publicly available quantitative predictors. The impact of the "missing data" is also telling. Kacperczyk, Sialm and Zheng (2008) demonstrate that the 
unobserved actions of fund managers (i.e. the interim trading that occurs between reporting dates) persistently create value for some managers, while destroying value for others. The resulting 'return gap' (i.e. the difference between inferred returns from periodically disclosed holdings and reported returns) was shown to predict fund performance. Puckett and Yan (2011) confirm this result by showing that interim trading skill is a persistent measure of investment ability, however they also demonstrate that quarterly reported holdings underestimate true excess returns by approximately $0.25 \%$ annually.

The primary concern that detractors voice against the public disclosure of fund manager holdings is the leakage of commercially sensitive information to competing investors. Agarwal, Mullally, Tang and Yang (2013) show that the SEC's introduction of quarterly holdings disclosure (from semi-annual disclosure) in 2004 led to smaller abnormal returns in superior funds, particularly for illiquid stocks and those which were subject to greater information asymmetry. Parida and Teo (2011) independently confirmed this by showing that semi-annually reporting fund managers with high abnormal returns in periods prior to 2004 no longer outperformed comparable quarterly reporting funds after the introduction of mandatory quarterly reporting. This shift was particularly profound in previously superior funds which held illiquid assets. For other market participants, 
however, the increased frequency in holdings disclosure led to greater liquidity in stocks with high fund ownership, and improved market quality (see Agarwal et al. (2013)).

A number of specific reasons have been cited for a decline in the performance of skilled managers in the context of more frequent portfolio disclosure. Wermers (2001) discusses the possibility of total shareholder returns from mutual fund investments decreasing with more frequent disclosure, due to both the front-running of mutual fund trades (e.g. when shifting a position, generating cash during a liquidity call, or for tax-loss selling purposes), and free-riding on fund investment strategies. The latter, known as 'copycat funds', have been shown to earn returns that are statistically indistinguishable, and possibly higher after fees, compared to original funds, when rebalancing is based on semi-annually disclosed fund holdings lagged up to 60 days from the snapshot date (e.g., see Frank, Poterba, Shackelford and Shoven (2004)). Furthermore, Verbeek and Wang (2013) show that the relative success of copycat funds significantly increased after 2004, when the SEC imposed quarterly disclosure regulations on all mutual funds. We build on these prior studies by investigating the performance of potential copycat funds across a number of different disclosure regimes, which also indirectly tests the time sensitivity of fund manager trades.

A periodic holdings disclosure regime may also lead to adverse agency effects. For example, Bhattacharyya and Nanda (2013) demonstrate how an informed fund manager, 
compensated on the basis of their fund's NAV, is incentivised to pump their portfolio (artificially ramping the price of held stocks prior to the reporting date) despite long-term damage to fund performance. Consistent with this view, Hu, McLean, Pontiff and Wang (2013) find that institutions do indeed buy stocks in which they already have large positions near year end. 


\section{Data}

We use a data set containing daily transactions and monthly holdings from 58 active Australian equity fund managers, spanning fifteen years from 1 January 1996 to 31 December 2010 inclusive. ${ }^{4}$ Previous research using this data set (see Chen, Foster, Gallagher and Wermers (2014)) and broader data sets of Australian fund managers (see Pinnuck (2003), Fong, Gallagher and Lee (2008)), has shown that fund managers do indeed appear to be skilled and highlighted the potential for copycat funds to exploit disclosed fund manager holdings.

The data were compiled through two phases of collection. In the first phase, carried out in 2002, fund managers were invited to provide daily transactions, holdings and aggregate performance data. These funds were selected in consultation with Mercer Investment Consulting, and were asked to provide information on their largest ${ }^{5}$ pooled active $^{6}$ Australian equity funds that were open to institution investors. This resulted in data for 33 fund managers who provided the requested data. The sample is skewed towards larger institutions, and is representative of the larger-sized managers available to investment.

\footnotetext{
${ }^{4}$ More recent data for portfolio holdings were not available, as the database had been collected at specific points through to only 2010. Collecting such data is labour intensive and relies on networks and providing comfort that the information will be held confidentially and used appropriately.

${ }^{5}$ Marked-to-market valuation of assets under management as of 31st December 2001

$6>1 \%$ target ex-ante tracking error
} 
The second phase, carried out in 2011, contributed the monthly holdings and daily trades of the underlying active managers in two large multi-manager funds. The first source comprises 11 underlying funds from a large open-ended fund-of-funds. The second source comprises 14 underlying funds from a large industry superannuation fund. In both cases, permission to collect fund trades and holdings data was sought from and granted by the multi-fund manager with no interaction with the underlying managers.

While this data set represents a restricted sample of Australian active fund managers, we believe it is nevertheless representative of the wider universe. Figure 1 presents the performance of our sample managers compared to the more comprehensive set of managers tracked by the Mercer Performance Analytics (MPA) database. Our data set provides a key advantage over most previous studies on fund manager performance evaluation: the daily transactions contained in our database allow us to evaluate trading performance on an inter-day basis, whereas previous studies (with the notable exception of Puckett and Yan (2011)) have been limited to, at best, monthly precision (e.g. Bennett, Gallagher, Harman, Warren and Xi (2013)). When evaluating stock trading ability in an environment of short-lived information and fleeting profitable opportunities, the granularity of data is a critical element (see Kothari and Warner (2001)).

Table 1, Panel A provides key statistics regarding the composition and trading activity in our database. Over the 1996 to 2010 period, our data set had a total of 58 fund 
managers who executed 96,276 buys and 85,131 sells. This was equivalent to approximately AU\$59 billion in purchases and AU\$57 billion in sales. Panel B presents a breakdown of trades by security characteristic. We observe that fund trades are primarily in large-cap stocks and stocks with low book-to-market ratios (i.e. growth-oriented stocks). Stocks with poor past returns are traded infrequently.

To complement our daily trade database, we also used daily price level and dilutions data from the SIRCA Australian Equities Tick History database, market capitalization and dividend data from the Share Price and Price Relative database, financial statement data from the Aspect Huntley database, and news announcements from SIRCA Core Research Data (CRD).

\section{Method and Discussion}

\subsection{Accuracy vs. Alpha Leakage}

In this section we analyse the reliability of reported portfolios in informing the returns and volatility of the underlying portfolio. The more frequently portfolio holdings are reported, the more accurate inferences regarding its return and volatility structures are likely to be (see Bollen and Busse (2001)). However, due to the cost of reporting and information leakage constraints, there must be an ideal frequency which facilitates accurate performance measurement, while concurrently protecting valuable intellectual 
property. In the US, this frequency was determined to be every six (6) months prior to 2004, and every three (3) months subsequently.

The reported portfolios comprise snapshots of the underlying funds taken at varying intervals (monthly, quarterly, semi-annual or annual). The return and risk characteristics of the reported portfolios are then computed using a buy-and-hold strategy that assumes each snapshot remains static until the next discrete snapshot. Performance is measured in terms of raw returns and cumulative abnormal returns (CARs), which are based on DGTW characteristics-based alpha. The latter benchmarks a stock's daily return against other stocks of similar size, book-to-market ratio and prior return characteristics. Unlike regression-based methods, it allows excess performance to be determined crosssectionally at high data frequency (see Daniel, Grinblatt, Titman and Wermers (1997)) for further details on the construction and rationalisation of the DGTW alpha benchmark). The abnormal return $\left(A R_{s t}\right)$ of a stock $s$ on day $t$ is defined as:

$$
A R_{s, t}=r_{s, t}-D G T W_{s, t}
$$

$r_{s t}$ is the dilution-adjusted arithmetic return of $s$ on day $t$ and $D G T W_{s t}$ is the return earned by the characteristic-based benchmark portfolio associated with $s$. We follow Pinnuck (2003) in using a 5 x 4 × 3 sort on size, book-to-market ratio and momentum, rather than the $5 \times 5 \times 5$ sort used by Daniel et al. (1997), to reflect the fact that there are fewer listed stocks on the ASX than on the US market. 
Over an $n$-day observation period, we use the cumulative abnormal return $\left(C A R_{n, s, t}\right)$ as our excess performance measure, given by:

$$
C A R_{n, s, t}=\prod_{i}^{n}\left(1+r_{s, t+i}\right)-\prod_{i}^{n}\left(1+D G T W_{s, t+i}\right)
$$

In the following sections, we look at two indicators of how reliably periodically reported portfolios are able to reflect the true performance of underlying funds.

\subsubsection{Expected error over long-term measurements}

Puckett and Yan (2011) demonstrate that fund managers in the United States generate statistically significant alpha in the intra-quartile period between SEC mandated $13 \mathrm{~F}$ reporting dates. We use Australian trades and portfolio holdings data to investigate whether a similar trend occurs in Australia, and to what extent short-term trade timing ability can be captured by a regime of periodic holdings disclosure. Table 2, Panel A compares the actual excess return against that inferred from reported holdings at intervals ranging from monthly to yearly. Actual fund returns vary between different reporting intervals, since longer reporting periods typically truncate the data towards the end - e.g. if a fund is included in the data set for 4 years and 9 months, then the final 3 months of data is discarded when measuring semi-annually reported performance, and the final 9 months of data is discarded when measuring annually reported performance. 
Table 2, Panel A suggests that, consistent with Puckett and Yan (2011), periodic reporting tends to underestimate true fund performance. The error appears to be most statistically significant at shorter reporting intervals (i.e. monthly and quarterly) though this can primarily be attributed to the smaller sample size when testing longer reporting periods. The small magnitude of mean measurement errors, however, hides the underlying variation between top-quartile performing managers and those in lower bands. Table 2 (Panel B) partitions the funds into quartiles by performance ranking based on mean DGTW alpha, which can only be measured with holdings level data. The results show that periodic holdings disclosure consistently underestimates true alpha for top-performing funds, whereas no such consistency is observed in lower bands. In addition, longer intervals between reporting tend to exacerbate the difference between a top-quartile manager's performance based on their reported portfolio and their true performance. Estimation errors in the best performing funds are a greater concern than in other funds, since prospective investors seek funds exhibiting evidence of consistent positive skill. Superior funds may be incentivised to disclose holdings more frequently than the minimum requirement, barring concerns in relation to possible copycatting (which is addressed in the next section).

While returns data is readily available to institutional investors for a wide range of managed funds (e.g. through industry surveys), data on the volatility of these returns are 
usually less accessible. Regularly disclosed portfolio holdings enable prospective investors to gauge the historical volatility and idiosyncratic risk of each fund through analysis of the reporting positions. Table 3, Panel A examines the accuracy with which the risk variables of reported portfolios match up with their actual risk. We use the standard deviation of annualised inter-day returns and DGTW characteristic-adjusted alphas to measure volatility and idiosyncratic risk. We do not find statistically significant differences between inferred and actual values of either measure of risk; this result is robust for volatility only when funds are divided by performance (Table 3, Panel B). Periodic reporting does significantly underestimate idiosyncratic volatility in top-quartile managers across all reporting frequencies (Table 3, Panel C), and this difference is substantially greater for longer inter-reporting periods. This suggests that top-quartile funds take large active bets in the interim period to drive performance.

Our results suggest that a periodic reporting system understates excess performance for top quartile performing managers, as well as their exposure to inter-day idiosyncratic volatility. Furthermore, the degree of under-reporting for both increases as the inter-reporting period lengthens. This may be an issue for performance-chasing prospective clients, as it makes top-performing funds (ex-post) difficult to identify, while at the same time masking the idiosyncratic risks that they take on to achieve higher alpha. 


\subsection{Copycat Funds}

The second part of this study addresses concerns around third parties exploiting the information released by fund managers for their own investment purposes. Specifically, we examine the profitability of a deterministic strategy where an otherwise uninformed investor buys and holds the disclosed portfolio positions of fund managers. This contrasts with front-running methods of exploitation, where savvy investors anticipate the net direction of future trades based on a fund manager's disclosed holdings (e.g. if a fund manager is steadily accumulating a position or needs to sell tax loss holdings at the end of a financial year) and enters the market ahead of the fund manager themselves.

The method we use follows Verbeek and Wang (2013). Using reported portfolios taken at varying intervals (monthly, quarterly, semi-annual and annually), we construct copycat funds which lag the snapshot date by a further one, three, six or twelve months. This reflects variations in possible 'grace periods' given to fund managers to lodge their portfolio holdings, similar to the 60-day grace period given to US mutual funds to submit their Section 13F filings. The copycat fund then employs a buy-and-hold strategy on the emulated portfolio until the next holdings snapshot is revealed. For the purpose of this study, we assume that transaction costs for the copycat fund are not significantly different from those of the underlying fund. 
We find a large dispersion of copycat fund outcomes relative to their underlying funds, however the mean difference in performance is not significantly different from zero across most reporting frequencies and lag periods (Table 4). The bias of the dispersion appears to be related to the performance of the underlying fund managers. To demonstrate this, we partition each fund into quartiles based on their mean DGTW characteristicsadjusted excess returns over the observation period. The hindsight bias introduced by this method effectively allows copycats perfect foresight with regard to fund performance rankings, and hence allows us to determine the effectiveness of copycat funds in the worst case scenario. A number of trends are immediately obvious in the results (Table 5): (a) copying a top/(bottom)-quartile fund based on their periodic disclosure tends to result in significant underperformance (outperformance); (b) lower reporting frequency amplifies the difference between copycat and underlying funds; and (c) longer lags enhance the effectiveness of copying top- and bottom-quartile funds.

Trend (a) suggests that top-quartile performing fund managers exploit short-term information advantages and produce significant excess returns through active trading. Copycat funds following superior managers are not able to capitalise on these timesensitive portfolio changes, and hence are not able to match the underlying fund's performance even when the copycat can identify (and indeed, forecast) which funds will be top-performing. Conversely, bottom-quartile fund managers appear to be selling 
holdings that subsequently outperform those that they buy. Because the copycat fund delays such trades, we observe relatively better performance in the copycats.

Trend (b) demonstrates that lower reporting frequencies exaggerate the difference between copycat funds and the underlying funds. Top-quartile performing funds outperform their copycats by even greater degrees when the mandated disclosure frequency is lower (e.g. every 6 or 12 months). This is applicable for all lags except the 12-month lag, where the underperformance of the copycat funds is economically significant but not statistically significant. Conversely, bottom-quartile funds are outperformed by their copycat funds to an even greater degree when the reporting frequency is decreased. This may be because, unlike the underlying funds, the copycat funds avoid non-profitable rebalancing during the intra-reporting period.

Trend (c) indicates that longer lags actually enhance the performance of copycat funds following first and fourth quartile funds. For copycat funds following first quartile managers, lagging the disclosed holdings by longer periods reduces the relative underperformance of the copycat. This may reflect the observation made by Chen et al. (2014) that the initial performance advantage of purchased stocks over sold stocks tends to revert over the medium and long term. At a 12-month lag, we find that the difference between copycat funds and underlying top-quartile funds are not statistically significant. On the other hand, copycat funds following bottom-quartile managers outperform their 
underlying funds even more significantly (both statistically and economically) when following at longer lags. This suggests that stocks sold by bottom-quartile funds continue to outperform those that they buy over the longer term, up to at least a year out from their respective transaction dates. We find that at the most frequent reporting period (monthly), top-quartile funds still outperform their copycat funds by $0.97 \%$ annualised (or $0.64 \%$ at a 12 month lag), which more than covers the typical range of institutional management fees $^{7}$. Furthermore, longer lags between reporting increase the advantage of top-quartile funds over copycats. Instituting longer lags between the holdings snapshot date and the public disclosure date does not appear to help protect fund managers' IP. Longer lags actually reduce the performance disadvantage associated with copying a top-tier fund, and increase the outperformance achieved when copying a bottom-tier fund.

\section{Conclusion}

Our study examines the potential impact of introducing mandatory portfolio holdings disclosure with respect to a market that currently has no mandated holdings disclosure regime. For Australia, by introducing a regulatory reporting regime informed by robust academic research, the potential outcomes could lead to the market reaping the benefits of a more efficient and effective funds management industry. Our findings suggest that high frequency disclosure of portfolio holdings increases the accuracy with

\footnotetext{
${ }^{7}$ Typically $0.3 \%$ to $0.7 \%$ of funds under management
} 
which reported holdings reflect the true performance of the underlying funds, without significantly impeding the competitiveness of funds that are most likely to be copied (i.e. top-quartile funds). We recognise that front-running of funds' transactions will still be a concern, however this requires a measure of skill in execution and is difficult to explicitly test ex-ante.

Disclosing portfolio holdings at monthly intervals results in inferred excess returns and volatilities that are significantly closer to those derived from daily holdings, particularly for top-quartile funds, where most investor interest is likely to be concentrated. We show that reporting at longer intervals significantly underestimates both the excess performance and volatility of top-tier funds, which may lead investors to undervalue these funds and underestimate the risks associated with these funds.

The results show that the perceived threat from copycat funds should not be a significant concern to top-tier funds because, at all reporting frequencies, these funds generate sufficient outperformance over the copycats to cover typical management fees. On the other hand, copycat funds may provide additional incentive for poor-performing managers to lift their performance, by improving their investment decisions and/or lowering their fees. The effectiveness of copycat funds does not appear to be degraded by increasing the lag between the snapshot date and the public disclosure date (within the range of 1 month to 1 year). From an investment client's perspective, more frequent 
disclosure incentivises improvements in trading performance while simultaneously providing a barrier to inflated management fees.

The Commonwealth Treasury undertook a review in 2013-14 (not yet finalised) titled 'Better regulation and governance, enhanced transparency and improved competition in superannuation ${ }^{8}$ which called for submissions in part on disclosure systems that could operate in the Australian superannuation industry. A natural extension to our study would be to examine the recommended system to be adopted, and the efficacy of this framework, once the Assistant Treasurer releases the final policy framework sometime in 2015.

\section{References}

Agarwal, V., Mullally, K., Tang, Y. \& Yang, B. 2013. Mandatory portfolio disclosure, stock liquidity, and mutual fund perfomance, Working paper (J. Mack Robinson College of Business, Georgia State University).

Alpert, B. N., Rekenthaler, J. \& Suh, S. 2013. Morningstar Global Fund Investor Experience 2013 Report.

Beekes, W., Brown, P. \& Zhang, Q. 2014. Corporate governance and the informativeness of disclosures in Australia: a re-examination, Accounting \& Finance Forthcoming.

\footnotetext{
8 http://www.treasury.gov.au/ConsultationsandReviews/Consultations/2013/Better-regulation-and-governance
} 
Bennett, S., Gallagher, D. R., Harman, G., Warren, G. J. \& Xi, L. 2013. Alpha generation in portfolio management: long-run Australian equity fund evidence, Working paper (UNSW Business School, UNSW Australia).

Bhattacharyya, S. \& Nanda, V. 2013. Portfolio pumping, trading activity and fund performance, Review of Finance, 17, 885-919.

Bollen, N. P. B. \& Busse, J. A. 2001. On the timing ability of mutual fund managers, The Journal of Finance, 56, 1075-1094.

Brown, K. \& Gregory-Allen, R. B. 2012. The potential effects of mandatory portfolio holdings disclosure in Australia and New Zealand, Working paper (School of Economics \& Finance, Massey University).

Chapple, L. \& Truong, T. P. 2014. Continuous disclosure compliance: does corporate governance matter? Accounting \& Finance Forthcoming.

Chen, Z., Foster, F. D., Gallagher, D. R. \& Wermers, R. 2014. A fourfold pattern to the art of active investing, Working paper (UNSW Business School, UNSW Australia). Daniel, K., Grinblatt, M., Titman, S. \& Wermers, R. 1997. Measuring mutual fund performance with characteristic-Based Benchmarks, The Journal of Finance, 52, 10351058

Elton, E. J., Gruber, M. J. \& Blake, C. R. 2011. Holdings data, security returns, and the selection of superior mutual funds, Journal of Financial and Quantitative Analysis, 46, 
341-367.

Fong, K., Gallagher, D. R. \& Lee, A. D. 2008. Benchmarking benchmarks: measuring characteristic selectivity using portfolio holdings data, Accounting \& Finance, 48, 761781.

Frank, M. M., Poterba, J. M., Shackelford, D. A. \& Shoven, J. B. 2004. Copycat funds: information disclosure regulation and the returns to active management in the mutual fund industry, The Journal of Law and Economics, 47, 515-541.

Hu, G., Mclean, R. D., Pontiff, J. \& Wang, Q. 2013. The year-end trading activities of instiutional investors: evidence from daily trades, Review of Financial Studies

Forthcoming, 1-23.

Kacperczyk, M., Sialm, C. \& Zheng, L. 2008. Unobserved actions of mutual funds, Review of Financial Studies, 21, 2379-2416.

Kothari, S. P. \& Warner, J. B. 2001. Evaluating mutual fund performance, The Journal of Finance, 56, 1985-2010.

Parida, S. \& Teo, T. 2011. The impact of more frequent portfolio disclosure on mutual fund performance, Working paper (Graduate School of Management, Clark University) Pinnuck, M. 2003. An examination of the performance of the trades and stock holdings of fund managers, Journal of Financial and Quantitative Analysis, 38, 811-828.

Puckett, A. \& Yan, X. S. 2011. The interim trading skills of institutional investors, The 
Journal of Finance, 66, 601-633.

Verbeek, M. \& Wang, Y. 2013. Better than the original? The relative success of copycat funds, Journal of Banking and Finance, 37, 3454-3471.

Wermers, R. 2001. The potential effects of more frequent portfolio disclosure on mutual fund performance, Perspective, 7, 1-12.

Wermers, R., Yao, T. \& Zhao, J. 2012. Forecasting stock returns through an efficient aggregation of mutual fund holdings, Review of Financial Studies, 25, 3490-3529. 


\section{Appendix}

Figure 1: Comparison of annual returns between the Mercer Portfolio Analytics (MPA) database and our proprietary data set. The MPA database consists of a total of 256 active fund managers (though the number is fewer at any single point in time).

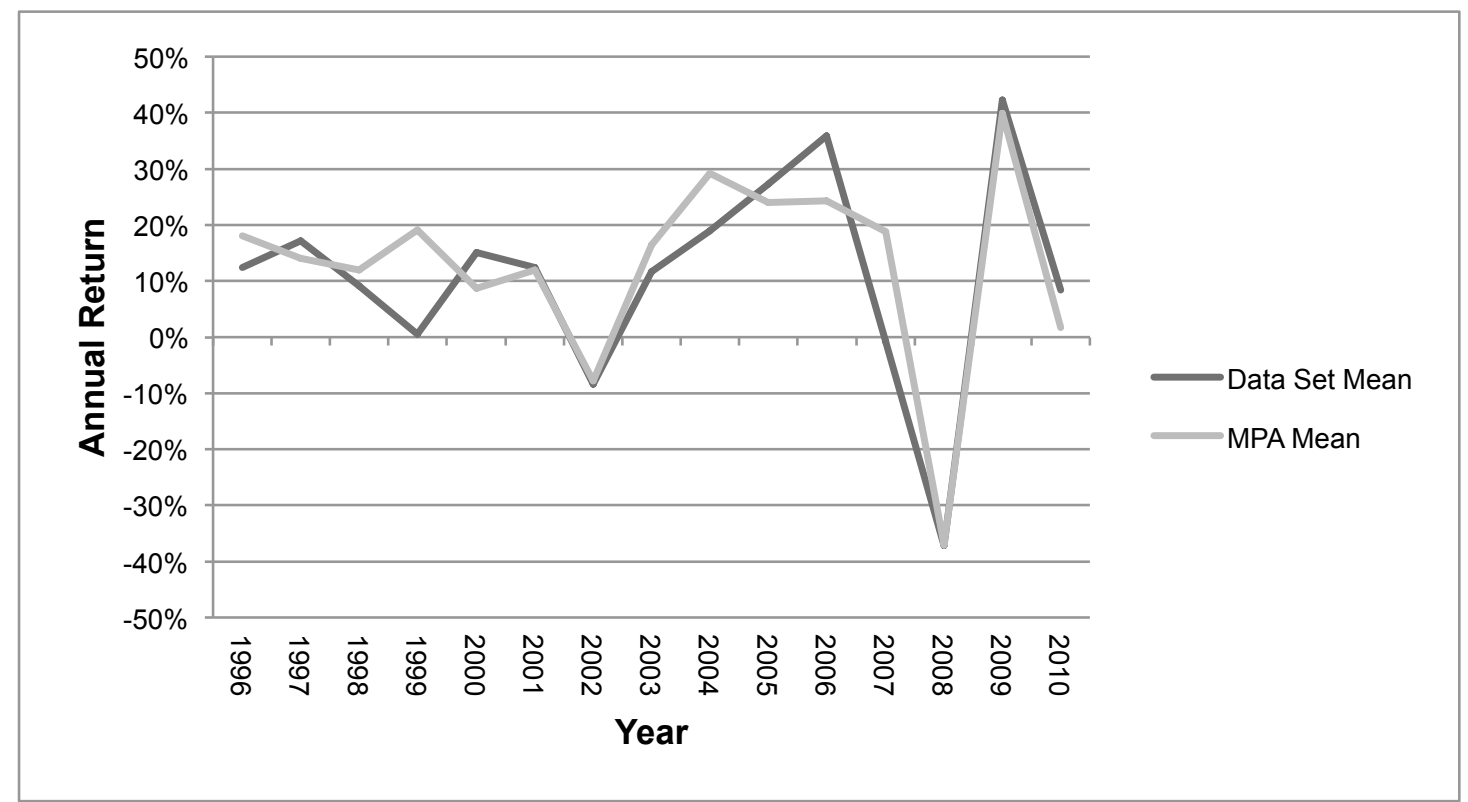


Table 1: Panel A displays the characteristics of our data set grouped by year. This data was collected from fund managers on a voluntary basis throughout the 1996 to 2010 period. Panel B presents the trade characteristics of the database based on size, book-tomarket ratio and prior year return. The information in this panel was synthesized with returns data sourced from the SIRCA Australian Equities Tick History database, market capitalization and dividend data from the SPPR database and financial statement data from the Aspect Huntley database. All monetary values are denominated in Australian dollars (AUD).

Panel A

\begin{tabular}{|c|c|c|c|c|c|}
\hline & 1996 & 1997 & 1998 & 1999 & 2000 \\
\hline No. of Managers & 13 & 15 & 20 & 25 & 31 \\
\hline Buys & 1956 & $\begin{array}{l}2969 \\
\$ 1,176.3\end{array}$ & $\begin{array}{l}4436 \\
\$ 2,319.8\end{array}$ & $\begin{array}{l}6547 \\
\$ 2,843.9\end{array}$ & $\begin{array}{l}10795 \\
\$ 4,956.5\end{array}$ \\
\hline Total Buy Value (\$m) & $\$ 716.48$ & 8 & 1 & 8 & 2 \\
\hline Sells & 1526 & $\begin{array}{l}2084 \\
\$ 1,010.2\end{array}$ & $\begin{array}{l}2865 \\
\$ 1,625.6\end{array}$ & $\begin{array}{l}5671 \\
\$ 2,610.3\end{array}$ & $\begin{array}{l}7736 \\
\$ 3,714.4\end{array}$ \\
\hline Total Sell Value (\$m) & $\begin{array}{l}\$ 603.48 \\
\$ 1,023.8\end{array}$ & $\begin{array}{l}6 \\
\$ 1,472.4\end{array}$ & $\begin{array}{l}7 \\
\$ 2,230.8\end{array}$ & $\begin{array}{l}5 \\
\$ 3,027.7\end{array}$ & $\begin{array}{l}1 \\
\$ 5,475.9\end{array}$ \\
\hline \multirow[t]{2}{*}{ Total Holdings (\$m) } & 2 & 3 & 3 & 0 & 0 \\
\hline & 2001 & 2002 & 2003 & 2004 & 2005 \\
\hline No. of Managers & 33 & 22 & 8 & 10 & 20 \\
\hline Buys & $\begin{array}{l}11697 \\
\$ 6,347.2\end{array}$ & 2009 & $\begin{array}{l}1863 \\
\$ 1,940.0\end{array}$ & $\begin{array}{l}2598 \\
\$ 3,007.1\end{array}$ & $\begin{array}{l}5777 \\
\$ 3,647.7\end{array}$ \\
\hline Total Buy Value (\$m) & 2 & $\$ 712.90$ & 5 & 7 & 5 \\
\hline Sells & $\begin{array}{l}10193 \\
\$ 5,356.3\end{array}$ & 1664 & $\begin{array}{l}2048 \\
\$ 2,309.9\end{array}$ & $\begin{array}{l}1947 \\
\$ 3,120.5\end{array}$ & $\begin{array}{l}4789 \\
\$ 3,799.3\end{array}$ \\
\hline Total Sell Value (\$m) & $\begin{array}{l}2 \\
\$ 7,987.7\end{array}$ & $\begin{array}{l}\$ 653.74 \\
\$ 3,713.9\end{array}$ & $\begin{array}{l}3 \\
\$ 3,809.0\end{array}$ & $\begin{array}{l}3 \\
\$ 5,098.1\end{array}$ & $\begin{array}{l}2 \\
\$ 9,010.1\end{array}$ \\
\hline Total Holdings (\$m) & 7 & 5 & 2 & 9 & 1 \\
\hline & 2006 & 2007 & 2008 & 2009 & 2010 \\
\hline No. of Managers & 19 & 20 & 25 & 26 & 24 \\
\hline Buys & $\begin{array}{l}6884 \\
\$ 4,496.6\end{array}$ & $\begin{array}{l}7408 \\
\$ 6,083.3\end{array}$ & $\begin{array}{l}10873 \\
\$ 9,335.3\end{array}$ & $\begin{array}{l}11370 \\
\$ 6,627.3\end{array}$ & $\begin{array}{l}9094 \\
\$ 5,038.2\end{array}$ \\
\hline Total Buy Value (\$m) & 0 & 1 & 1 & 0 & 2 \\
\hline Sells & $\begin{array}{l}6072 \\
\$ 4,913.5\end{array}$ & $\begin{array}{l}7258 \\
\$ 6,346.4\end{array}$ & $\begin{array}{l}10691 \\
\$ 8,738.4\end{array}$ & $\begin{array}{l}12427 \\
\$ 8,066.1\end{array}$ & $\begin{array}{l}8160 \\
\$ 4,102.9\end{array}$ \\
\hline $\begin{array}{l}\text { Total Sell Value (\$m) } \\
\text { Total Holdings (\$m) }\end{array}$ & $\begin{array}{l}4 \\
\$ 10,700 . \\
61\end{array}$ & $\begin{array}{l}1 \\
\$ 14,357 . \\
05\end{array}$ & $\begin{array}{l}3 \\
\$ 14,072 . \\
99\end{array}$ & $\begin{array}{l}5 \\
\$ 12,741 \\
59\end{array}$ & $\begin{array}{l}4 \\
\$ 11,593 . \\
12\end{array}$ \\
\hline
\end{tabular}


Panel B

\begin{tabular}{|c|c|c|c|c|c|}
\hline $\begin{array}{l}\text { Size } \\
\text { Ranking }\end{array}$ & $\begin{array}{l}\text { Trade } \\
\text { Value } \\
\%\end{array}$ & $\begin{array}{l}\text { Book-to- } \\
\text { Market Quintile }\end{array}$ & $\begin{array}{l}\text { Trade } \\
\text { Value } \\
\%\end{array}$ & $\begin{array}{l}\text { Prior Year } \\
\text { Return } \\
\text { Quintile }\end{array}$ & $\begin{array}{l}\text { Trade } \\
\text { Value } \\
\%\end{array}$ \\
\hline $1-50$ & $\begin{array}{l}73.64 \\
\% \\
16.44\end{array}$ & 1 (Low B/M) & $27.64 \%$ & 1 (Lowest) & $3.49 \%$ \\
\hline $\begin{array}{l}51-100 \\
101-\end{array}$ & $\%$ & 2 & $34.83 \%$ & 2 & $16.88 \%$ \\
\hline $\begin{array}{l}200 \\
201-\end{array}$ & $7.80 \%$ & 3 & $23.96 \%$ & 3 & $30.28 \%$ \\
\hline 300 & $1.62 \%$ & 4 & $9.17 \%$ & 4 & $27.43 \%$ \\
\hline $300+$ & $0.49 \%$ & $5(\operatorname{High} \mathrm{B} / \mathrm{M})$ & $4.40 \%$ & 5 (Highest) & $21.93 \%$ \\
\hline
\end{tabular}


Table 2: Comparison of DGTW fund alphas derived from reported holdings at different disclosure frequencies versus actual underlying fund alphas (Panel A), and when partitioned into quartiles by fund alpha (Panel B). Each quartile contains approximately 15 funds in Panel B. Percentages represent annualised DGTW characteristics-based excess returns (see main text for construction method and rationale). Actual fund alphas vary due to differences in included data for the different reporting intervals (see main text for details). Results are based on trades and holdings data described in the Data section, as well as daily price level and dilutions data from the SIRCA Australian Equities Tick History database, market capitalization and dividend data from the Share Price and Price Relative database and financial statement data from the Aspect Huntley database.

\begin{tabular}{|c|c|c|c|}
\hline \multicolumn{4}{|c|}{ Panel A } \\
\hline & $\begin{array}{c}\text { Reported } \\
\text { Fund } \\
\text { Alpha } \\
\end{array}$ & $\begin{array}{c}\text { Actual } \\
\text { Fund } \\
\text { Alpha }\end{array}$ & $\begin{array}{c}\text { Alpha } \\
\text { Difference }\end{array}$ \\
\hline Monthly & $2.00 \%$ & $2.18 \%$ & $-0.17 \% * * *$ \\
\hline Quarterly & $2.08 \%$ & $2.26 \%$ & $-0.18 \% * * *$ \\
\hline Semi-annual & $1.80 \%$ & $1.96 \%$ & $-0.16 \% *$ \\
\hline Yearly & $1.48 \%$ & $1.82 \%$ & $-0.34 \% * *$ \\
\hline
\end{tabular}

$* * *<1 \%$ significance, $* *<5 \%$ significance, $*<10 \%$ significance

\begin{tabular}{l|llll}
\hline \multicolumn{2}{l|}{ Panel B } \\
& Monthly & Quarterly & $\begin{array}{c}\text { Semi- } \\
\text { annual }\end{array}$ & Yearly \\
\hline Quartile 1 - best & $-0.46 \% * * *$ & $-1.00 \% * * *$ & $-0.76 \% * * *$ & $-1.14 \% * * *$ \\
Quartile 2 & $-0.22 \% * *$ & $-0.13 \%$ & $-0.25 \%$ & $-0.75 \% * *$ \\
Quartile 3 & $-0.05 \%$ & $0.05 \%$ & $0.01 \%$ & $0.09 \%$ \\
Quartile 4 - worst & $-0.04 \%$ & $0.03 \%$ & $0.23 \%$ & $0.48 \%$ \\
\hline
\end{tabular}

$* * *<1 \%$ significance, $* *<5 \%$ significance, $*<10 \%$ significance 
Table 3: Errors between volatility (standard deviation of inter-day returns) and idiosyncratic volatility (standard deviation of inter-day DGTW alpha) measured from periodically disclosed holdings snapshots, and those of the true portfolio (Panel A). Results have also been partitioned into quartiles of approximately 15 funds by underlying fund alpha for volatility (Panel B) and idiosyncratic volatility (Panel C). Underlying daily returns were annualised to produce annualised volatility measurements, and consequently annualised differences in volatility. Negative errors denote the reported portfolios exhibiting lower volatility and idiosyncratic volatility than the true portfolios. Results are based on trades and holdings data described in the Data section, as well as daily price level and dilutions data from the SIRCA Australian Equities Tick History database, market capitalization and dividend data from the Share Price and Price Relative database and financial statement data from the Aspect Huntley database.

Panel A

\begin{tabular}{l|cc}
\hline & $\begin{array}{c}\text { Inter-day Returns } \\
\text { Volatility Error }\end{array}$ & $\begin{array}{c}\text { Inter-day Idiosyncratic } \\
\text { Volatility Error }\end{array}$ \\
\hline Month & $0.05 \%$ & $0.01 \%$ \\
Quarter & $-0.06 \%$ & $-0.03 \%$ \\
Semi- & & \\
annual & $0.08 \%$ & $-0.18 \%$ \\
Year & $0.56 \%$ & $-0.26 \%$ \\
\hline
\end{tabular}

$* * *<1 \%$ significance, $* *<5 \%$ significance, $*<10 \%$ significance

Panel B

\begin{tabular}{l|llll}
\hline & Monthly & Quarterly & Semi-annual & Yearly \\
\hline Quartile 1 - best & $-0.21 \%$ & $-0.15 \%$ & $-0.12 \%$ & $0.51 \%$ \\
Quartile 2 & $0.06 \%$ & $-0.05 \%$ & $-0.20 \%$ & $1.01 \%$ \\
Quartile 3 & $0.33 \%$ & $0.39 \%$ & $0.49 \%$ & $-0.23 \%$ \\
Quartile 4 - worst & $-0.02 \%$ & $-0.35 \%$ & $0.13 \%$ & $0.97 \%$ \\
\hline
\end{tabular}

$* * *<1 \%$ significance, $* *<5 \%$ significance, $*<10 \%$ significance

Panel C

\begin{tabular}{l|llll}
\hline & \multicolumn{1}{|c}{ Monthly } & Quarterly & \multicolumn{1}{c}{ Semi-annual } & \multicolumn{1}{c}{ Yearly } \\
\hline & & & & - \\
Quartile 1 - best & $-0.44 \% * * *$ & $-0.94 \% * *$ & $-1.52 \% * *$ & $2.84 \% * *$ \\
Quartile 2 & $-0.03 \%$ & $0.24 \%$ & $-0.41 \%$ & $0.94 \%$ \\
Quartile 3 & $0.40 \%$ & $0.31 \%$ & $-0.11 \%$ & $0.86 \%$ \\
Quartile 4 - worst & $0.03 \%$ & $0.13 \%$ & $0.19 \%$ & $-0.69 \%$ \\
\hline
\end{tabular}

$* * *<1 \%$ significance, $* *<5 \%$ significance, $*<10 \%$ significance 
Table 4: Differences in DGTW alphas between copycat funds and the underlying funds across four different reporting periods and 4 different lags. Results are based on trades and holdings data described in the Data section, as well as daily price level and dilutions data from the SIRCA Australian Equities Tick History database, market capitalization and dividend data from the Share Price and Price Relative database and financial statement data from the Aspect Huntley database.

\begin{tabular}{ll|cccc}
\hline & & \multicolumn{4}{|c}{ Reporting Period (Months) } \\
& & 1 & 3 & 6 & 12 \\
\hline Lag & 1 & $-0.12 \%$ & $-0.14 \%$ & $-0.12 \%$ & $-0.36 \% * *$ \\
(Months & 3 & $0.04 \%$ & $-0.11 \%$ & $-0.11 \%$ & $-0.18 \%$ \\
) & 6 & $-0.04 \%$ & $-0.10 \%$ & $-0.02 \%$ & $0.35 \%$ \\
& 12 & $0.32 \%$ & $0.27 \%$ & $0.34 \%$ & $0.41 \%$ \\
\hline
\end{tabular}

$* * *<1 \%$ significance, $* *<5 \%$ significance, $*<10 \%$ significance 
Table 5: Differences in DGTW alphas between copycat funds and the underlying funds across four different reporting periods and 4 different lags (Panel A). Results have been partitioned into quartiles by underlying fund performance (as measured by mean alpha actually generated) with the first quartile being the best performing fund managers and the fourth quartile being the worst. Each quartile contains approximately 15 funds (Panel B). Results are based on the same data as that described in the previous table.

\section{Panel A}

\begin{tabular}{ll|cccc}
\hline & & \multicolumn{4}{|c}{ Reporting Period (Months) } \\
& & 1 & 3 & 6 & 12 \\
\hline Lag & 1 & $-0.12 \%$ & $-0.14 \%$ & $-0.12 \%$ & $-0.36 \% * *$ \\
(Months & 3 & $0.04 \%$ & $-0.11 \%$ & $-0.11 \%$ & $-0.18 \%$ \\
) & 6 & $-0.04 \%$ & $-0.10 \%$ & $-0.02 \%$ & $0.35 \%$ \\
& 12 & $0.32 \%$ & $0.27 \%$ & $0.34 \%$ & $0.41 \%$ \\
\hline
\end{tabular}

$* * *<1 \%$ significance, $* *<5 \%$ significance, $*<10 \%$ significance 


\section{Panel B}

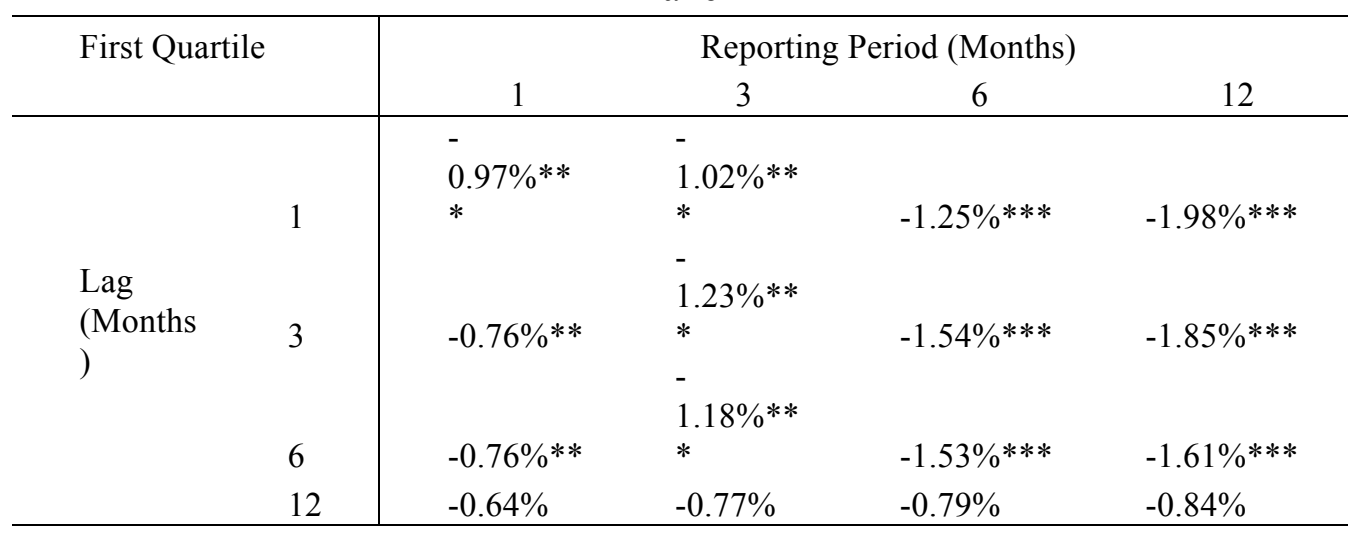

\begin{tabular}{ll|clll}
\hline \multicolumn{2}{l|}{ Second Quartile } & \multicolumn{4}{|c}{ Reporting Period (Months) } \\
& & 1 & \multicolumn{1}{c}{3} & \multicolumn{1}{c}{6} \\
\hline \multirow{2}{*}{ Lag } & 1 & $-0.15 \%$ & $-0.08 \%$ & $-0.40 \% *$ & $-0.83 \% * *$ \\
(Months & 3 & $-0.13 \%$ & $-0.35 \%$ & $-0.30 \%$ & $0.03 \%$ \\
) & 6 & $-0.55 \%$ & $-0.86 \% * *$ & $-0.48 \%$ & $0.32 \%$ \\
& 12 & $-0.49 \%$ & $-0.28 \%$ & $-0.06 \%$ & $-0.47 \%$ \\
\hline
\end{tabular}

\begin{tabular}{ll|cccc}
\hline \multicolumn{2}{l|}{ Third Quartile } & \multicolumn{4}{|c}{ Reporting Period (Months) } \\
& 1 & 1 & 3 & 6 & 12 \\
\hline \multirow{2}{*}{ Lag } & 3 & $0.24 \%$ & $0.02 \%$ & $0.16 \%$ & $0.21 \%$ \\
(Months & 6 & $0.37 \%$ & $0.39 \%$ & $-0.01 \%$ & $-0.27 \%$ \\
& 12 & $0.59 \% *$ & $0.46 \%$ & $0.52 \%$ & $0.54 \%$ \\
& & & & $0.21 \%$ & $0.62 \%$ \\
\hline
\end{tabular}

\begin{tabular}{|c|c|c|c|c|c|}
\hline \multirow{2}{*}{\multicolumn{2}{|c|}{ Fourth Quartile }} & \multicolumn{4}{|c|}{ Reporting Period (Months) } \\
\hline & & 1 & 3 & 6 & 12 \\
\hline \multirow{5}{*}{$\begin{array}{l}\text { Lag } \\
\text { (Months } \\
\text { ) }\end{array}$} & 1 & $0.15 \%$ & $0.33 \%$ & $0.76 \%$ & $0.85 \% * * *$ \\
\hline & 3 & $0.33 \% * *$ & $0.29 \% * *$ & $0.83 \% * *$ & $1.02 \% * * *$ \\
\hline & 6 & $\begin{array}{l}0.62 \% * * \\
*\end{array}$ & $\begin{array}{l}0.77 \% * * \\
*\end{array}$ & $0.99 \% * * *$ & $0.94 \% * * *$ \\
\hline & & $1.73 \% * *$ & $1.73 \% * *$ & & \\
\hline & 12 & $*$ & $*$ & $2.00 \% * *$ & $2.26 \% * *$ \\
\hline
\end{tabular}

\footnotetext{
$<1 \%$ significance, $* *<5 \%$ significance, $*<10 \%$ significance
} 